\title{
Effect of Feeding Different Levels of Pigeon peal (Cajanus cajan) and Season, on Carcass Characteristics of Nubian Goat Kids
}

\author{
Dr. Omer Massaad Elbashier ${ }^{1}$, Pro. Shadia A. Omer ${ }^{2}$ \\ ${ }^{1,2}$ Sudan University of Science and Technology, College of Veterinary Medicine and Animal production
}

\begin{abstract}
This study was conducted at the College of Veterinary Medicine and Animal Production Farm, Sudan University, at Hillat Kuku, in Sudan. To investigate the effect of feeding different levels of pigeon peas and season on some carcass characteristics of 40 male Nubian goat kids, in replacement of groundnut cakes. Two experiments were conducted, both for 10 weeks, during winter and summer season. Results showed that most of the carcass characteristics were influenced $(P<0.05)$ by dietary treatments and season. All parameters values were high for feeding $20 \%$ pigeon peas in the winter season. The results have shown that, the highest mean values were $45.77^{d} \pm 0.63,2.42^{d} \pm 0.91$ and54.09 \pm 3.41 for the carcass yield, shrinkage, and muscles percentage respectively. The lowest values were $44.75 \%$, $6.02 \%$ and $53.21 \%$ for the above parameters respectively for the control groups, fed zero\% C.cajan, in the summer season. Bone content, muscle bone ratio, and fat percentage varied significantly with both feed and season, being the highest values were $26.62 \%, 2.05 \%$, and17.11\% respectively, obtained by groups fed $20 \%$ pigeon peas in the winter season, while the lowest values were $22.11 \%, 1.97 \%$ and 11.85 for the above parameters respectively obtained by the control groups, fed zero\% pigeon peas, in the summer season. It is clear that pigeon peas seeds can be added to ruminants feed up to20\% of the ration, without any side effects. On all parameters tested, it was superior to groundnut cakes, especially during the winter season. It was concluded that pigeon pea seeds can replace groundnut cakes in feeding ruminants.
\end{abstract}

Keywords: C.cajan, groundnut cakes, summer season, winter season, carcass characteristics

\section{Introduction}

Scarcity and high cost of conventional protein feedstuffs in Sudan has made the need for sustainable nutritional practices as a means of coping and managing the livestock sector in Sudan by utilization of non-conventional protein feedstuffs, for low cost effective livestock production.

Pigeon pea(Cajanus cajan), local names (pigeon peas, Dhal, Gandul, Red gram, Congo pea, No eye pea). It is a leguminous crop, widely cultivated in all tropical andsemitropical regions of both the Old and New Worlds. The Indian subcontinent, Eastern Africa and Central America, are the world's three main pigeon pea-producing regions. Pigeon peas are very draught resistant, so can be grown in areas with less than $650 \mathrm{~mm}$ annual rainfall. Pigeon pea can be of a perennial variety, in which the crop can last three to five years, or an annual variety which is more suitable for seed production. The crop is cultivated on marginal land. Traditionally, the use of such input as fertilizers, weeding, irrigation, and pesticides is minimal, so the present yield levels are low (average $=700 \mathrm{~kg} / \mathrm{ha}$ ). Greater attention now is being given to managing the crop because of it is in high demand at remunerative prices(Henri,1991)

Pigeon pea is grown traditionally in Northern Sudan, Geziera and Rahad irrigated schemes in about 700.000 hectares,yielding about $700 \mathrm{~kg} / \mathrm{feddan}$, it is produced in abundant quantities, which alwaysexceeds the human consumption, so its price may fall to a level that makes it`s use as an animal feed economically [6].

[9],reported that the chemical analysis of Pigeon pea reveals that,it contains: 2'-0'methylcajanone, 2'- hydroxygenistein, 5,7,2'-trihydroxyisoflavone, alphaamyrin, beta-amryin, beta-sitosterol, cajaflavanone, cajaisoflavone, cajanin, cajanone, cajaquinone, concajanin, ferreirin, genistein, isogenistein-7-0-glucoside, lupeol, phenylalanine, stigmasterol and the protein contents of whole seed ranged from 20.78 to $21.5 \%$, fat from 1.53 to $1.89 \%$, crude fiber from 8.29 to $8.63 \%$, NFE from 52.57 to $55.35 \%$ and ash content ranged from 4.67 to $4.76 \%$. The protein, fat crude fiber, NFE and ash of the cooked dhals were $6.69 \%, \quad 0.74 \%, 1.91 \%, 22.4 \%$ and $1.37 \%$ respectively. Nine mineral elements, $\mathrm{Na} . \mathrm{K}, \mathrm{P}, \mathrm{Ca}, \mathrm{Cu}, \mathrm{Zu}$, $\mathrm{Fe}$ and $\mathrm{Mn}$ were determined,[25].

[17]studied the amino acids and minerals content of pigeon pea and found that it contains nutritionally useful quantities of the most essential amino acids. The total amino acids were equal to $43.6 \%$, also they found thatleulenic and palmetic acids were the most predominant fatty acids, with an average of $54.80 \%$ and $21.40 \%$ respectively in the oil of pigeon pea.Ithas been reported that pigeon pea is rich in lysine amino acid (ranged between $6.2-7.29 \mathrm{~g} \backslash 100$ protein Sridhar and. [20]found that pigeon pea is rich in essential and non- essential amino acids than groundnuts cakes.

Laboratory, studies with animals, reports that Pigeon pea seeds have some anti-nutritional qualities such as trypsin inhibitors and chymotrypsin inhibitors which reduce or inhibit pancreatic amylase and lipase. The plant has a high feeding value for beef and dairy cattle, sheep and goats. [9]. Pigeon pea plays an important role in food and nutritional security because it is a rich source of protein, minerals and vitamins. Pigeon pea seeds are mainly consumed as split pea soups or 'dal' but a significant proportion is also eaten as green pea vegetable and as 


\section{International Journal of Science and Research (IJSR) \\ ISSN (Online): 2319-7064}

Index Copernicus Value (2013): 6.14 | Impact Factor (2015): 6.391

wholegrain preparations. In addition, pigeon pea leaves, seed husks and pods are used as animal feed, whereas the stem and branches are used as firewood. (Nagendra et al, 2011).

\section{Materials and Methods}

The study was conducted at the Farm of College of Animal Production Science and Technology, Sudan University of Science and Technology, Kuku area. Two experiments were conducted, in the cool, during the period 12/12/2014 to $22 / 2 / 2015$ and hot dry seasons, during the period $1 / 4$ / to $10 / 6 / 2015$, in orderto study the effect of feeding various levels of pigeon pea $(0,10,15$ and $20 \%)$ and theeffect of season on some carcass characteristic parameters of Nubian goat kids.

\section{Experiment Diet}

The ingredients of the rations, as shown in table (1), were purchased from Kuku Local Market. Four rations were formulated according to the [16], to satisfy the requirement for maintenance and growth of the kids. Ingredients were the same for both experiments), they were isocolaric and isonitrogenous.

Table 1: Ingredients of the Experimental Rations

\begin{tabular}{|c|c|c|c|c|}
\hline pigeon pea & zero & 10 & 15 & 20 \\
Groundnut cake & 20 & 15 & 13 & 11 \\
Molasses & 15 & 10 & 7 & 4 \\
Sorghum & 25 & 25 & 25 & 25 \\
Wheat bran & 36 & 36 & 36 & 36 \\
Ground nut hulls & 2 & 2 & 2 & 2 \\
Limestone & 1 & 1 & 1 & 1 \\
Salt & 1 & 1 & 1 & 1 \\
\hline
\end{tabular}

Table 2: Proximate Analysis of Pigeon pea (\% DM).(cool dry season)

\begin{tabular}{|c|c|c|c|c|c|c|}
\hline $\mathrm{Q} M$ & $E . E$ & $C P$ & $C F$ & $A s h$ & $N F E$ & $M E$ \\
$\%$ & $\%$ & $\%$ & $\%$ & $\%$ & $\%$ & Kcal $/ g$ \\
\hline $\mathbf{9 1 . 3 7}$ & $\mathbf{2 . 4 8}$ & $\mathbf{2 8 . 5 0}$ & $\mathbf{1 0 . 7 0}$ & $\mathbf{5 . 3 9}$ & $\mathbf{4 4 . 2 0}$ & $\mathbf{1 0 . 8 9}$ \\
\hline
\end{tabular}

Table 3: Proximate Analysis of Groundnut Cake (\% DM)(hot dry season)

\begin{tabular}{|c|c|c|c|c|c|c|}
\hline $\begin{array}{c}\text { QM } \\
\%\end{array}$ & $\begin{array}{c}\text { E.E } \\
\%\end{array}$ & $\begin{array}{c}\text { CP } \\
\%\end{array}$ & $\begin{array}{c}\text { CF } \\
\%\end{array}$ & $\begin{array}{r}\text { Ash } \\
\%\end{array}$ & $\begin{array}{c}\text { NFE } \\
\%\end{array}$ & $\begin{array}{c}\text { ME } \\
\text { Kcal/g }\end{array}$ \\
\hline 90.4 & 4.2 & 43.1 & 10.1 & 4.2 & 30.1 & 11.9 \\
\hline
\end{tabular}

Table 4: Proximate Analysis of the Experimental Rations (\% DM).

\begin{tabular}{|c|c|c|c|c|c|c|c|}
\hline $\begin{array}{c}\text { Variable } \\
\text { Rations }\end{array}$ & $\begin{array}{c}D M \\
\%\end{array}$ & $\begin{array}{c}E . E \\
\%\end{array}$ & $\begin{array}{c}C P \\
\%\end{array}$ & $\begin{array}{c}C F \\
\%\end{array}$ & $\begin{array}{c}A s h \\
\%\end{array}$ & $\begin{array}{c}\text { NFE } \\
\%\end{array}$ & $\begin{array}{c}M E \\
\text { Kcal } / g\end{array}$ \\
\hline A & 91.61 & 4.15 & 20.11 & 9.15 & 5.05 & 53.16 & 10.93 \\
B & 91.44 & 4.70 & 20.25 & 8.10 & 5.15 & 53.20 & 11.48 \\
C & 91.95 & 3.55 & 20.75 & 7.90 & 5.34 & 54.82 & 11.80 \\
D & 91.90 & 3.00 & 20.05 & 8.20 & 6.35 & 54.30 & 11.60 \\
\hline
\end{tabular}

\section{Experimental Animals}

Forty intact male Nubian goat kids were purchased from Abuzied Livestock Market in Omdurman. Their age ranged between $2-3$ months with an average live weight of approximately $10 \mathrm{kgs}$. They were selected according to the nearest external features for the Nubian goats.

Prior to kid's arrival, eight pens were prepared, each pen measuring $2 \times 3$ meters. The sides were made of rabbit wire; the roof was made of metal sheets and insulated using local materials. On arrival, animals were treated againstboth externaland internal parasites and treated with an antibiotic as a prophylactic measures.Animals were left for seven days adaptation period. Animals were weighed and ear tagged. They were divided randomly into four groups A, $\mathrm{B}, \mathrm{C}$ and $\mathrm{D}$ with an average weight of $10 \mathrm{kgs}$. Each group was further divided into two subgroups, 5 animals for each subgroup. Animals were fed the assigned experimental feed diet at 7:30 a.m.(adlibitum). The residue of the feed was collected every morning before offering feed, to determine daily feed intake. Clean water and salt lick, were available at all times. Abusabeen (Sorghum Stover) was offered daily at noontime; at a rate of $0.4 \mathrm{~kg} / \mathrm{head} / \mathrm{day}$. Alfa Alfa (Medicago sativa); was offered weekly at a rate of $0.5 \mathrm{~kg} / \mathrm{head} /$ day.Animals were weighed weekly before the morning meal, for the whole period.

Five kids were selected randomly from each group andslaughtered; after 24 hours fasting. Empty carcasses were weighed immediately to determine the hot carcasses weights, then carcasses were chilled at $4 \mathrm{c}$ for 24 hours, the next morning, the chilled carcasses were weighed and carcasses shrinkage was calculated.Carcasses were divided into two equal halves; the left half from each carcass was cut into neck, shoulder, back and lion. Carcasses cuts were dissected into bones, muscles and fat to determine muscle, bone and fat percentage from the chilled carcasses andfor muscle bone ratio.as described by (Gaili1979).

\section{Statistical Analysis:-}

All data was subjected to analysis of variance, the influence of feed was examined for significance by ANOVA, while the effect of season was examined by student $t$ testas described by [13], using SPSS (version 10),

\section{Results and Discussion}




\section{International Journal of Science and Research (IJSR) ISSN (Online): 2319-7064}

Index Copernicus Value (2013): 6.14 | Impact Factor (2015): 6.391

Table 5: Carcass characteristics of Nubian goat kids fed different levels of pigeon pea (winter season)

\begin{tabular}{|c|c|c|c|c|c|}
\hline $\begin{array}{ll}\text { Parameters } & \text { Groups } \\
\end{array}$ & $\mathrm{A}(\mathrm{M} \pm \mathrm{SD})$ & $\mathrm{B}(\mathrm{M} \pm \mathrm{SD})$ & $\mathrm{C}(\mathrm{M} \pm \mathrm{SD})$ & $\mathrm{D}(\mathrm{M} \pm \mathrm{SD})$ & $\begin{array}{c}\text { Level of } \\
\text { significance }\end{array}$ \\
\hline Number of animals & 5 & 5 & 5 & 5 & \\
\hline Duration (days) & 70 & 70 & 70 & 70 & \\
\hline Slaughter body weight ( kg) & $13.98^{\mathrm{b}} \pm 1.41$ & $14.11^{b} \pm 1.39$ & $14.29^{b} \pm 1.06$ & $16.50^{\mathrm{a}} \pm 2.71$ & ** \\
\hline Hot carcass $(\mathrm{kg})$ & $6.46^{\mathrm{b}} \pm 0.72$ & $6.64^{b} \pm 0.51$ & $6.88^{b} \pm 0.61$ & $7.56^{\mathrm{a}} \pm 1.74$ & $* *$ \\
\hline Carcass yield (\%) & $45.77^{\mathrm{d}} \pm 0.63$ & $46.17^{\mathrm{c}} \pm 0.61$ & $47.93^{\mathrm{a}} \pm 1.21$ & $46.94^{b} \pm 0.93$ & $*$ \\
\hline Cold carcass (kg) & $6.29^{c} \pm 0.82$ & $6.40^{c} \pm 0.92$ & $6.69^{b} \pm 0.61$ & $7.39^{\mathrm{a}} \pm 1.01$ & $* *$ \\
\hline Shirking (\%) From hot carcass & $3.28^{b} \pm 0.32$ & $3.61^{\mathrm{a}} \pm 0.41$ & $2.67^{\mathrm{c}} \pm 0.32$ & $2.42^{\mathrm{d}} \pm 0.91$ & $* *$ \\
\hline Muscle (\%) From cold carcass & $56.01^{\mathrm{b}} \pm 0.71$ & $57.71^{\mathrm{a}} \pm 0.60$ & $56.11^{b} \pm 2.62$ & $55.05^{\mathrm{c}} \pm 1.21$ & $*$ \\
\hline Bone $(\%)$ From cold carcass & $26.62^{\mathrm{a}} \pm 1.91$ & $25.42^{b} \pm 2.81$ & $25.31^{\mathrm{b}} \pm 1.91$ & $25.20^{b} \pm 2.37$ & $*$ \\
\hline Muscle : Bone ratio & $2.05^{\mathrm{a}} \pm 0.24$ & $2.27^{\mathrm{a}} \pm 0.15$ & $2.24^{\mathrm{a}} \pm 0.13$ & $2.37^{\mathrm{a}} \pm 0.17$ & $*$ \\
\hline Fat (\%) From cold carcass & $11.07^{\mathrm{d}} \pm 1.90$ & $12.61^{\mathrm{c}} \pm 1.41$ & $14.10^{b} \pm 1.31$ & $17.11{ }^{\mathrm{a}} \pm 1.91$ & $* *$ \\
\hline
\end{tabular}

Ration content of C.cajan: A 0.0\%, B $10 \%$, C $15 \%$, D $20 \%$

The values are means \pm standard deviation, they are replicate of 5 animals for each group.

$=$ Significant at $(P<0.05) . * *=$ Significant at $(P<0.01)$. NS=Not Significant.

$a, b, . .=$ means with in the same row followed by different superscript are significantly different

Table 5: Carcass characteristics of Nubian goat kids fed different levels of pigeon pea (summer season)

\begin{tabular}{|c|c|c|c|c|c|}
\hline Groups & $\mathrm{A}(\mathrm{M} \pm \mathrm{SD})$ & $\mathrm{B}(\mathrm{M} \pm \mathrm{SD})$ & $\mathrm{C}(\mathrm{M} \pm \mathrm{SD})$ & $\mathrm{D}(\mathrm{M} \pm \mathrm{SD})$ & $\begin{array}{c}\text { Level of } \\
\text { significance }\end{array}$ \\
\hline Parameters & & 5 & 5 & 5 & \\
\hline Number of animals & 70 & 70 & 70 & 70 & \\
\hline Duration (days) & $10.59^{\mathrm{d}} \pm 1.21$ & $11.63^{\mathrm{c}} \pm 0.37$ & $12.44^{\mathrm{b}} \pm 0.47$ & $13.90^{\mathrm{a}} \pm 1.90$ & $* *$ \\
\hline Slaughter body weight ( kg) & $4.81^{\mathrm{c}} \pm 0.62$ & $5.27^{\mathrm{b}} \pm 0.76$ & $5.49^{\mathrm{b}} \pm 0.22$ & $6.24^{\mathrm{a}} \pm 0.62$ & $* *$ \\
\hline Carcass yield (\%) Slaughter body weight & $44.75^{\mathrm{b}} \pm 2.50$ & $44.41^{\mathrm{c}} \pm 0.50$ & $44.61^{\mathrm{b}} \pm 1.20$ & $45.86^{\mathrm{a}} \pm 1.10$ & $*$ \\
\hline Cold carcass (kg) & $4.52^{\mathrm{c}} \pm 0.98$ & $5.00^{\mathrm{b}} \pm 0.72$ & $5.26^{\mathrm{b}} \pm 0.63$ & $6.00^{\mathrm{a}} \pm 1.13$ & $* *$ \\
\hline Shirking (\%) From hot carcass & $6.02^{\mathrm{a}} \pm 0.71$ & $5.40^{\mathrm{b}} \pm 0.80$ & $4.18^{\mathrm{c}} \pm 0.62$ & $3.84^{\mathrm{d}} \pm 0.31$ & $* *$ \\
\hline Muscle (\%) From cold carcass & $54.09^{\mathrm{b}} \pm 3.41$ & $53.62^{\mathrm{c}} \pm 5.41$ & $55.36^{\mathrm{a}} \pm 2.12$ & $53.21^{\mathrm{d}} \pm 4.41$ & $*$ \\
\hline Bone (\%) From Cold carcass & $23.02^{\mathrm{b}} \pm 2.91$ & $22.11^{\mathrm{c}} \pm 1.91$ & $24.81^{\mathrm{a}} \pm 0.75$ & $24.76^{\mathrm{a}} \pm 1.61$ & $*$ \\
\hline Muscle : Bone ratio & $2.00^{\mathrm{a}} \pm 0.29$ & $1.97^{\mathrm{a}} \pm 0.34$ & $2.06^{\mathrm{a}} \pm 0.21$ & $1.97^{\mathrm{a}} \pm 0.16$ & $\mathrm{NS}$ \\
\hline Fat (\%) From cold carcass & $11.85^{\mathrm{d}} \pm 1.07$ & $13.30^{\mathrm{c}} \pm 1.42$ & $14.50^{\mathrm{b}} \pm 1.91$ & $15.76^{\mathrm{a}} \pm 2.41$ & $* *$ \\
\hline
\end{tabular}

Ration content of C.cajan : A $0.0 \%$, B $10 \%$, C $15 \%$, D $20 \%$

The values are means \pm standard deviation, they are replicate of 5 animals for each group.

$=$ Significant at $(\mathrm{P}<0.05) . * *=$ Significant at $(\mathrm{P}<0.01)$. NS=Not Significant.

$\mathrm{a}, \mathrm{b}, . .=$ means with in the same row followed by different superscript are significantly different

Table 6: Effect of the season on carcass characteristics of Nubian goat kids fed different levels of pigeon pea

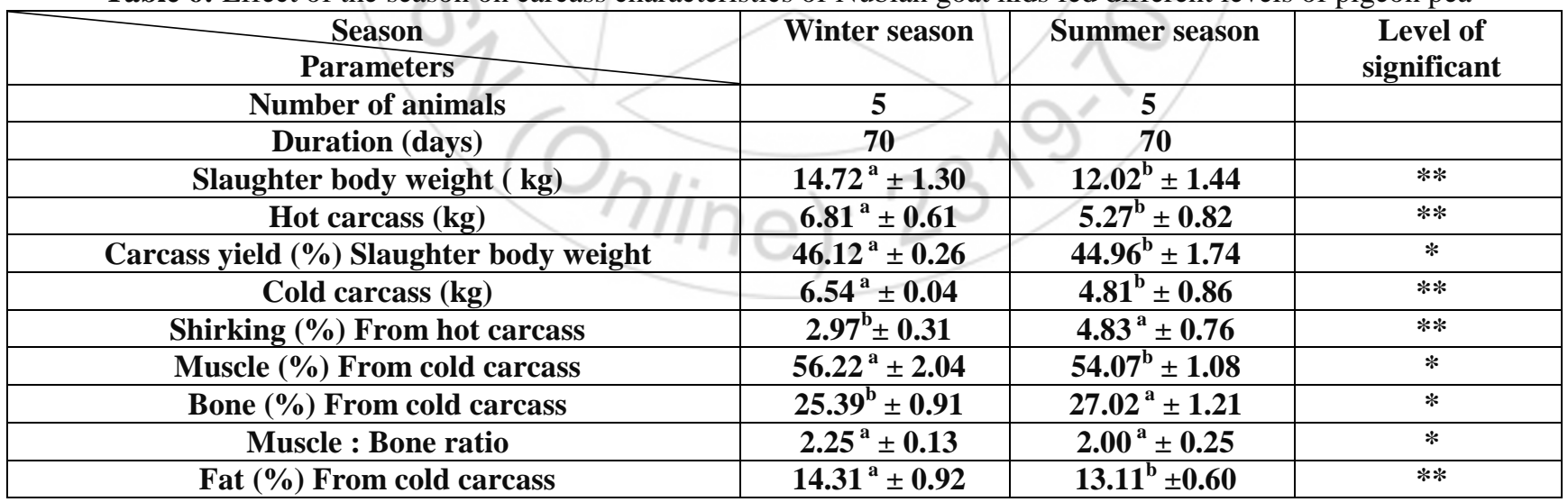

Ration content of C.cajan : A $0.0 \%$, B $10 \%$, C $15 \%$, D $20 \%$

The values are means \pm standard deviation, they are replicate of 5 animals for each group.

$=$ Significant at $(P<0.05) . * *=$ Significant at $(P<0.01)$. NS=Not Significant.

$a, b, . .=$ means with in the same row followed by different superscript are significantly different

\section{Discussion}

As seen in tables (5, 6 and 7) that hot and cold carcasses weights showed a positive relationship with slaughter weights. These findings are comparable with that reported by Ibrahim and [9]
In this study the dressing percentage varied significantly among all groups, due to the effect of season and feed. The mean values of carcass yield percentage ranged between $44.75 \%$ and $47.93 \%$ for summer and winter seasons respectively. These values are slightly higher than the results obtained by [6], who reported dressing percentage of $43.3 \%$ in desert goats fed on groundnut cakes. The 


\section{International Journal of Science and Research (IJSR) \\ ISSN (Online): 2319-7064}

Index Copernicus Value (2013): 6.14 | Impact Factor (2015): 6.391

present results are in accordance with the values recorded by [24] and [5].

Fat deposition varied with both feed and season. A negative response existed between shrinkage percentage and fat deposition. As seen in table (5) and (6) there was a direct relationship between carcass shrinkage and fat deposition, mainly subcutaneous fat, the more fat deposited in carcasses; the less shrinkage percentage, that means fat acts as an insulator to prevent evaporation of water from carcasses.The shrinkage mean values were $2.42 \%$ obtained for group D in the winter and $6.06 \%$ obtained from the control group in the summer season. Shrinkage mean values are in accordance with $2.60-$ $5.36 \%$ in Sudan desert goat kids, recorded by [18].

The total carcass lean percentage varied significantly among groups due to feed as well as season. The mean values of lean percentage ranged between $53.21 \%$ and $57.71 \%$, recorded in summer and winter season trial kids respectively. The recent results are superior to those recorded by [4] and [19], reported a range of $44.6 \%$ $49.4 \%$ in Angora goats, which are lower than the range obtained in this study.

Bone percentage showed significant variations among the groups due to both season and feed. Bone percentage was high compared to values obtained by [9], [8] and [18].

Muscle bone ratio M: B values ranged between 1.97 and 2.37. The winter season experiment results were slightly higher than the summer season values. These results compared favourably with the values recorded by [19], who reported a range of 1.82 -2.46 for Angora goats.

The high fat percentage results for groups C and D in both seasons, clarify that the feeding of higher levels of pigeon pea in the diet resulted in more fat deposition, which could be explained by the faster degradation of rations containing high level of pigeon pea.

Meat colour values varied significantly $(p<0.01)$ between groups in the winter season. The meat colour is mainly affected by the level and the state of myglobin and haemoglobin in the muscles. The present finding revealed high values of red colour for groups $\mathrm{C}$ and $\mathrm{D}$ which fed higher levels of pigeon pea in the diet, this could be explained by the high content of methionine and cysteine amino acids in the seeds of pigeon pea, which are the essential amino acids for protein synthesis [21] and to the fact that pigeon pea contains high level of iron, which is essential for the synthesis of haem in the haemoglobin molecule[14], The results revealed high values of brightness for groups A (control) in both seasons, a result which may suggest that animals which did not have pigeon pea in the diet have got less myglobin in their muscles.

\section{Conclusion}

It can be conducted that pigeon pea Cajanus cajan can be fed up to $20 \%$ in the rations for feeding goats as a protein source without side effects and it improved carcass characteristics.

\section{Acknowledgement}

We would like to thank Sudan University administration staff for their financial support.

\section{References}

[1] AhamefuleF.O. and M.D. Udo. Dry Matter Intake and Digestibility in West African Dwarf Goats Fed Raw or Processed Pigeon Pea (Cajanus Cajan) SeedIranian Journal of Applied Animal Science. Volume: 1; Number: 1; Pages: 2008, 17-21University of Agriculture, Umudike Abia State, Nigeria.

[2] Ahamefule F.O. Evaluation of pigeon pea-cassava peel based diets for goat's production in South-Eastern Nig. Ph.D. Thesis. Michael Okpara University of Agriculture, 2005, Umudike, Abia State, Nigeria.

[3] Basit Ali Shah. Nutritional evaluation of pigeon pea (Cajanus cajan) Thesis,Institute of Chemistry/ 1999, University of the Punjab. Pakistan.

[4] Bellow A.M.Performance and carcass characteristics of Sudan desert goat kids compared with their temperate crosses. M.V.Sc. Thesis, 1985, University of Khartoum, Sudan.

[5] Devendra, C. Goat production in the Asian region; current status, available genetic resource and potential prospects. International Goat and sheep Research

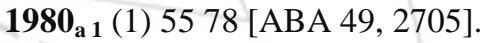

[6] Elhaj, F. M and Elwakeel, A. S).Forage legume hay as a dry season supplement for goats in the North Kordofan .Sudan J. Agri. Res. Elobied. Research Station, Elobied, Sudan,1998, 1: 1: $41-44$.

[7] Elkhidir, O.A.; Khalafalla, A.M.; Suleiman, Y.R. and Merges, F.I. Effect of traditional fattening of Kenana cattle.Sudan J. Ani. Prod. 1988, 1(1) 1-6.

[8] Elsayed, A.A.A comparative study on the carcass characteristics of Sudan desert sheep and goats 1981, M. Sci. Thesis, Faculty of Vet. Sci. Univ. of Khartoum, Sudan.

[9] Gaili, E.S.F. Body composition of male Sudan desert goat.WorId. Review of An.Prod. 1982, 12 (2)83 - 88.

[10] Henry, A., Krishna, G.V. Correlation and path coefficient analysis in pigeon pea.Madras Agric. J., 1990, 77(9, 12), 44446.

[11] Ibrahim, A. The nutritive value of proposes chilensis "Molina" (Mosquite) pods for feeding goats. Sudan J. Animal Part vol1999, 12: $1-4$.

[12] Ibrahim, A. and Gaili, E.S.E.Relationship of slaughter in carcass data in Sudan desert goats. World Review of Ani.Prod1982, .18 (4): 22 25.Mangalagangotri 574 1999, Karnataka, India sirikr@yahoo.com

[13] Marija J. Norusis and Inc. SPSS Inc. PASWStatistics Guide to Data Analysis, 2010, Prentice Hall, London

[14] Meineres, C.R.; Derise, N.L., Lau, H.C.; Crew, M.G.; Ritchey, S.J. and Murph, E.W.The content of raw and cooked mature 3

[15] Nagendra K Singh, Sutapa Dutta, Giriraj Kumawat' Bikram P Singh, Deepak K Gupta, Sangeeta Singh, Vivek Dogra, Kishor Gaikwad, Tilak R Sharma, 


\section{International Journal of Science and Research (IJSR) \\ ISSN (Online): 2319-7064}

Index Copernicus Value (2013): 6.14 | Impact Factor (2015): 6.391

Ranjeet S Raje, Tapas K Bandhopadhya, Subhojit Datta, Mahendra N Singh, Fakrudin Bashasab, Pawan Kulwal, KB Wanjari, Rajeev K Varshney, Douglas R Cook and Nagendra K Singh*', Development of genicSSR markers by deep transcriptome sequencing in pigeonpea [Cajanus cajan (L.) Millspaugh] BMC Plant Biology doi: 2011, 10.1186/1471-2229-11-17

[16] NCR, National Research Counci, Nutrients Requirements of Goats. National Academy Press, 1981, Washington D.U.S.A.

[17] Oshodi, I. Amino acids, fatty acids and minerals of C. cajan. International J. of Food Sci. and Nutrition, 1993, 43 (4): 18191.

[18] Osman, B.M. The effect of feeding molasses and low quality roughage on performance and body composition of goats1984, M.V.Sc. Thesis Faculty of Veterinary Science University of Khartoum.

[19] Shahjalal, Md., Galbraith, H. and Topps, J. H. "The effect of changes in dietary protein and energy on growth, body composition and mohair fibre characteristics of British Angora goats." Animal Production.1992, 54: 405-.

[20] Singh, U. and Eggum, B. B. Amino acid Composition of C. cajan. Plant Food for Human Nutrition, 34: 273 - 28. Plant Food for Human Nutrition. 1984, 31: 354

[21] Singh, U. and Jambunathan, R. Distribution of seed protein fractions and amino acids in different anatomical parts of chick and pigeon pea. Plant Food for Human Nutrition. 1982, 31: 354

[22] Sridhar, K. R. and Rajeev Bhat Agrobotanical, nutritional and bioactive potential of unconventional legume -2007Mucuna Microbiology and Biotechnology, Department of Biosciences, Mangalore University,

[23] Whiteman, P.C. and B.W. Norton. Alternative uses pigeon pea. IN. Proceedings of the International Workshop on Pigeon peas, Volume1. 15-19 December 1980, ICRISAT, India.

[24] Wilson, P.N.The Effect of Plane of Nutrition on the Growth of African Dwarf Goats. J. of Agr. Sci. U. K. 1958, 5: 14 - 21374.

[25] Yuan-gang Zu, Xiao-lei, Yu-jie Fu, NanWu, YuKong, Michael W .Chemical composition of the SFE-CO2 extracts from Cajanus cajan (L.) Huth and their antimicrobial activity in vitro and in vivo. .2010, 17:1095-101. Phytomed; and Microbiology and Biotechnology, Department of Biosciences, Mangalore University,

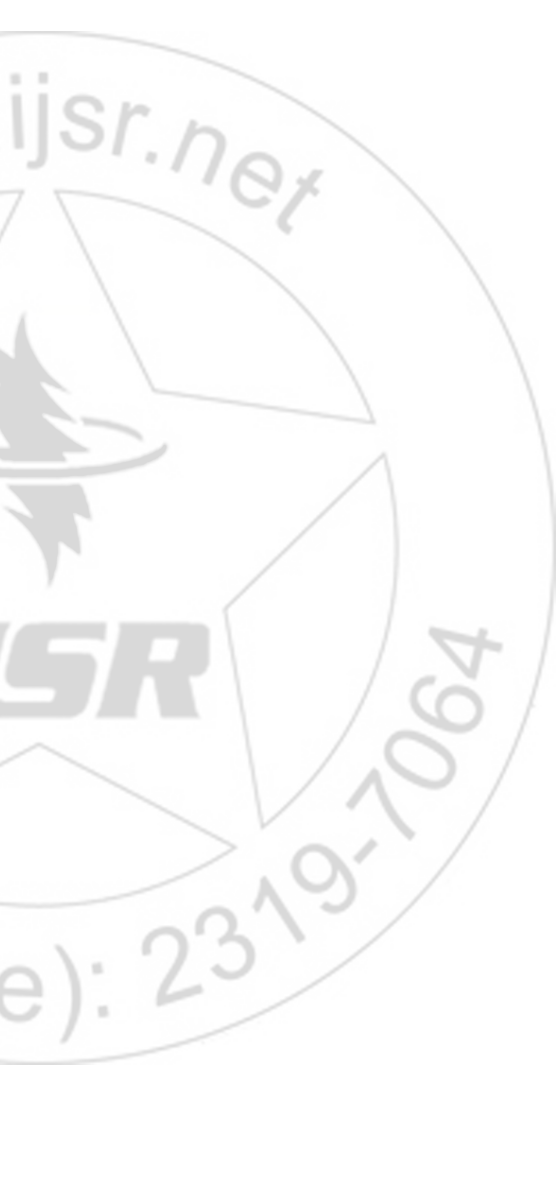

